Ann. Génét. Sél. anim., I980, 12 (I), 9-I3.

\title{
Udder conformation and its heritability in the Assaf (Awassi $\times$ East Friesian) cross of dairy sheep in Israel
}

\author{
E. GOOTWINE*, B. ALEF** and S. GADEESH*** \\ * Institute of Animal Science, Agricultural Research Organization, Bet Dagan, Israel \\ ** Sheep Breeding Section, Ministry of Agriculture, Israel \\ *** Moshav Moledet, Isvael
}

\section{Summary}

A survey of udder conformation in 544 ewes, 2-5 years old, and 269 hoggets after first lambing, all belonging to the Assaf Cross (Awassi $\times$ East Friesian) was performed. Twentyseven per cent of the ewes possessed udders unsuited for milk fractionation. Analyses made in a half-sister group of udder shape, teat location, teat length and teat thickness showed $h^{2}$ of I.I $\pm 0.45,0.42 \pm 0,23,0.38 \pm 0.26,0.23 \pm 0.25$, respectively. No significant correlation was found between udder shape and milk production.

\section{Introduction}

In machine milking ewes, good fractionation of milk yield is a desirable trait. Machine or hand stripping delays the process of milking and thus sometimes not all the milk is taken from the ewe.

SAGI and MoRAG (I974) showed the pattern of milk fractionation could be related to udder conformation. Ewes with udders with low teats showed better performance than ewes with udders having high teats. Although the use of a mechanical udder support improved milk fractionation, there is still an advantage to ewes having udders with low teats (SAGI, I978).

The great variation that was found in udder conformation in the Awassi breed in Israel by Sharav et al. (I962) strengthens the idea that there is room for a breeding program that will improve the udder conformation in the dairy ewe.

During recent years, the Assaf cross (Awassi $\times$ East Friesian) was introduced into Israel owing to its high prolificacy compared to the Awassi breed (Goot, I966). There are now over 5 ooo heads of this cross in the country, which 
constitutes about Io $\mathrm{p}$. Ioo of the total dairy sheep. This work presents a study of the frequency of udder types in the cross and estimates the genetic part of the phenotypic variability. The possible connection between udder shape and milk production is investigated.

\section{Material and Methods}

A survey of udder conformation was performed in the Assaf dairy flock belonging to Moshav Moledet, near Afula, Israel. This flock is maintained under intensive management and kept indoors during the whole year. Nearly half of the ewes lamb twice a year. The flock consisted of nearly I ooo dairy ewes; in this work 269 hoggets after first lambing and 544 2-to-5-year old ewes were included.

Udder examination took place between 20 to 60 days after lambing during the first milk recording in the lactation. In order to classify the udder conformation its shape was characterised by 4 sub-traits, with 4 grades in each category, according to table $I$.

TABLE I

Udder Classification

Classification des mamelles

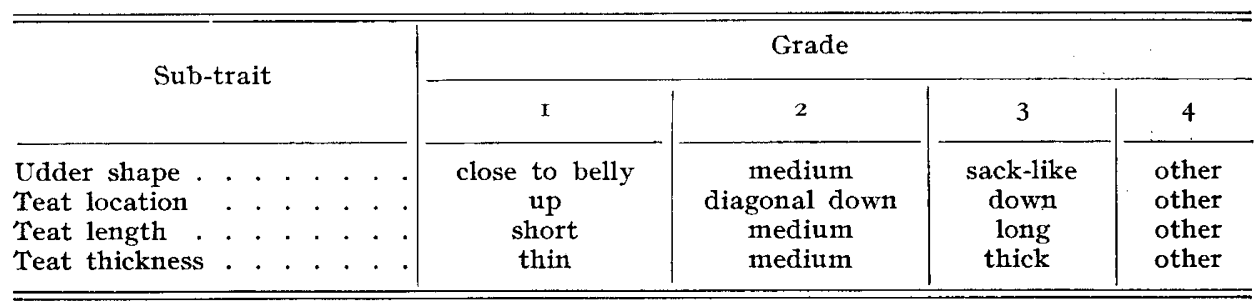

Estimation of milk production during the first roo days of the lactation was based on three successive monthly milk recordings. During the days of the recording the lambs continued the usual regime of suckling the residual milk, remaining after the milking.

Heritability of udder shape calculations were performed on $45^{\mathrm{I}}$ half-sisters between 2 to 5 years old that were in the flock at the time of udder typing. The ewes were daughters of I 9 rams and the size of the half-daughter groups ranged between 9 and 47 ewes.

The calculations of heritability and of mother-daughter correlation were performed after excluding the undefined cases (grade 4 in table I) and after reclassification of the sub-traits as follows :

$$
\begin{aligned}
& \text { Udder shape - sack-like shape or not; } \\
& \text { Teat location - up of not; } \\
& \text { Teat length - short or not; } \\
& \text { Teat thickness - thin or not. }
\end{aligned}
$$

Heritability calculation of the udder conformation was performed according to HILL and SMITH (I977). 


\section{Results}

The frequency of the sub-traits of the udder conformation as defined in table $I$ is presented in table 2 .

Table 2 shows that 27 per roo ewes have udders which are classified as undesireable, according to SAGI (I978), in relation to milk fractionation. Comparing

TABLE 2

Udder conformation in 269 hoggets after first lambing $(\mathrm{H})$

and in 544 ewes 2-5-years old (E)

Conformation de la mamelle chez 269 antenaises après leur premier agnelage

et chez 544 brebis âgées de 2 à 5 ans

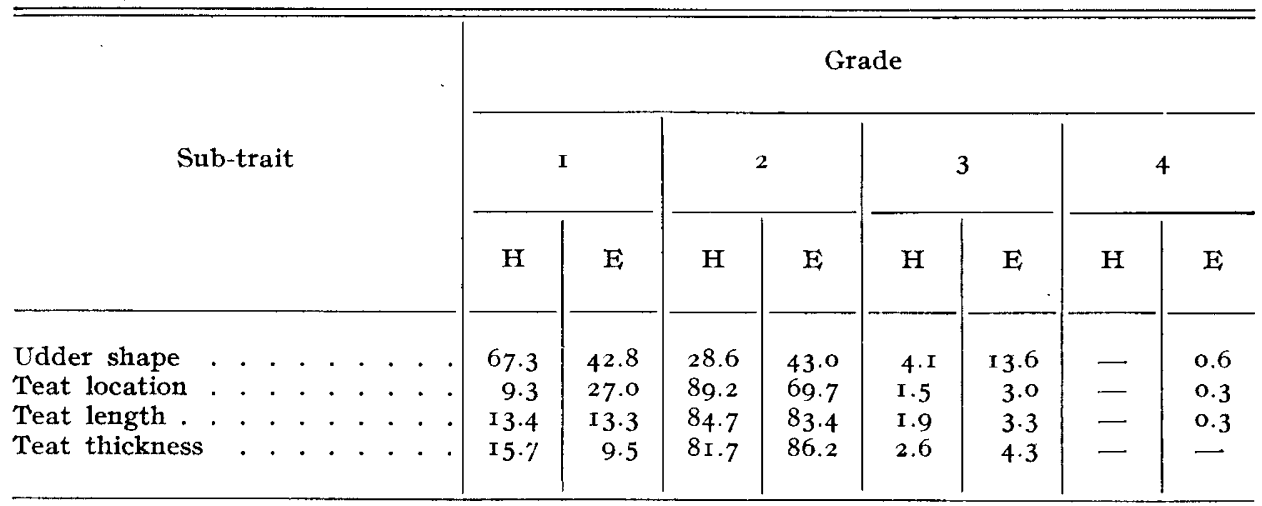

Numbers represent the p. roo of hoggets or ewes receiving the grade from the total number of the group.

the data from hoggets and ewes it can be seen that, while there is no difference in teat length and thickness, there is a significant $(\mathrm{P}<0.05)$ difference in udder shape and location of the teats.

Values of heritability of the sub-traits are presented in table 3. Heritability values that were calculated were found to be high and medium despite the fact that typing of the udders was done by sight only.

Among the ewes that were examined there were 68 mother-daughter pairs. The frequency of udder sub-traits in the two groups was examined by $\chi^{2}$-test and in the case of teat location there was a significant connection $(\mathrm{P}<0.05)$.

The lack of significant correlation in the other udder sub-traits among the mother-daughter pairs seems to be due to the relatively low frequency of some of the ratings in this sample.

The mean \pm S.D. milk production of the hoggets and ewes during the first IOo days of the lactation was $\mathrm{I} 92 \pm 5 \mathrm{I}$ liters and $223 \pm 62$ liters, respectively. No significant differences were found either between ewes from different ages $(2$ to 5 years) or between ewes raising singles or twins. 
TABLE 3

Heritability of udder conformation calculated from $45^{I}$ half-sisters (daughters of I9 “xms! Héritabilité de la conformation de la mamelle estimée par corrélation entre demi-sours $(n=45 I)$, filles de I9 béliers

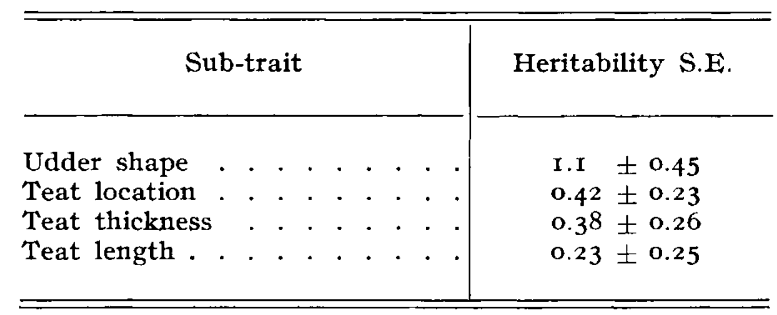

Testing the differences between the mean milk production of the rg halfsister group showed that the differences are not significant, $F_{18} / \mathbf{3 9 8}=0.75$.

No significant correlation was found between the udder shape of the ewe and her milk production.

\section{Discussion}

Poor milk fractionation of the dairy ewe can be explained in part by udder conformation. Adaptation of the udder to the demands of machine milking can be achieved both by genetic and mechanical means (FLAMANT, r974). By putting together the factors of good udder type and mechanical support, the machine milk fraction can be brought up to $7 \mathrm{I} \mathrm{p}$. Ioo compared to the case of bad udder conformation without support which releases only $44 \mathrm{p}$. Ioo during the machine milking period, according to SAGI (I978).

In the present study, we found that in the Assaf cross in Israel 27 per roo of the ewes have unsuitable udders as regards milk fractionation. The high values of heritability obtained for udder shape and teat location indicate that improvement could be achieved by selection. Moreover, the typing of the udder can be done by simple methods suitable to farm conditions.

It is necessary that the typing takes place as early as possible in the life of the ewe; however, it is known that the udder conformation changes either between or within lactations (IATSCH, I977). Thus, typing procedures ought to first take place at the beginning of the second lactation and must be performed during successive lactations.

In this study no connection was found between the udder shape and milk production of the ewe. It seems that selection for udder shape is relevant mainly to the milk fractionation.

\section{Résumé}

La conformation de la mamelle et son héritabilité chez les brebis laitières Assaf (Awassi $\times$. Frisonne de l'Est) en Israël

Un examen de la conformation de la mamelle chez 554 brebis de type $A$ ssaf (Awassi $\times$ Frisonne de l'Est), âgées de 2-5 ans, et 269 antenaises après leur premier agnelage, a montré que 27 p. I oo des animaux possédaient un type de mamelle défectueux entraînant de mauvaises 
caractéristiques de traite (pourcentage de lait restant dans la mamelle important). Les coefficients d'héritabilité $\left(h^{2}\right)$ de la forme de la mamelle, de la localisation, de la longueur et de l'épaisseur des trayons obtenus par corrélation entre demi-sœurs, intra paire, sont respectivement $1,1 \pm 0,45$, $0,42 \pm 0,23,0,38 \pm 0,26,0,23 \pm 0.25$. On n'a trouvé aucune corrélation significative entre la conformation de la mamelle et la production de lait.

Reçu pour publication en mai I980

\section{References}

Flamant J. C., 1974. Genetic improvement of milkability in ewes and goats. Symposium sur la traite mécanique de petits ruminants, Institut National de la Recherche Agronomique, Paris. I974.

Goor H., I966. Studies on the native Awassi sheep and its crosses with the exotic East Friesian milk sheep. Pamphlet No I 5 , Agricultural Research Organization, Bet Dagan, Israel.

HILI W. G., SMITH C., I977. Estimation heritability of a dichotomous trait. Biometrics, 33, 234-236.

IATSCH O., 1977. Ph. D. Thesis, University of Giessen.

SAGI R., 1978. Udder support as a means for improving milk fractionation in dairy ewes. $A n n$. Zootech., 27, 347-353.

SAGI R., MORAG M., I974. Udder conformation, milk yield and milk fractionation in dairy ewes. Ann. Zootech., 23, I85-r92.

Sharav A., Volcani R., Eyal, F., 1962. A survey of udder conformation of Awassi sheep. Ktavim, 12, 99-107 (Hebrew). 